Supporting Information for

\title{
Ratiometric Detection of $\gamma$-Glutamyltransferase in Human Colon Cancer Tissues using a Two-photon Probe
}

\author{
Yun Ji Kim, ${ }^{\text {ta }}$ Sang Jun Park, ${ }^{\text {ta }}$ Chang Su Lim, ${ }^{a}$ Dong Jun Lee, ${ }^{a}$ Choong-Kyun Noh, ${ }^{b}$ Kiyoun Lee, ${ }^{\mathrm{c}}$ \\ Sung Jae Shin, ${ }^{*}$ b Hwan Myung Kim ${ }^{*}, \mathrm{a}$ \\ ${ }^{a}$ Department of Energy Systems Research and Department of Chemistry, Ajou University, Suwon
} 16499, Korea,E-mail: kimhm@ajou.ac.kr.

${ }^{b}$ Department of Gastroenterology, Ajou University School of Medicine, Suwon 16499, Korea.

${ }^{c}$ Department of Chemistry, The Catholic University of Korea, Bucheon 14662, Korea 


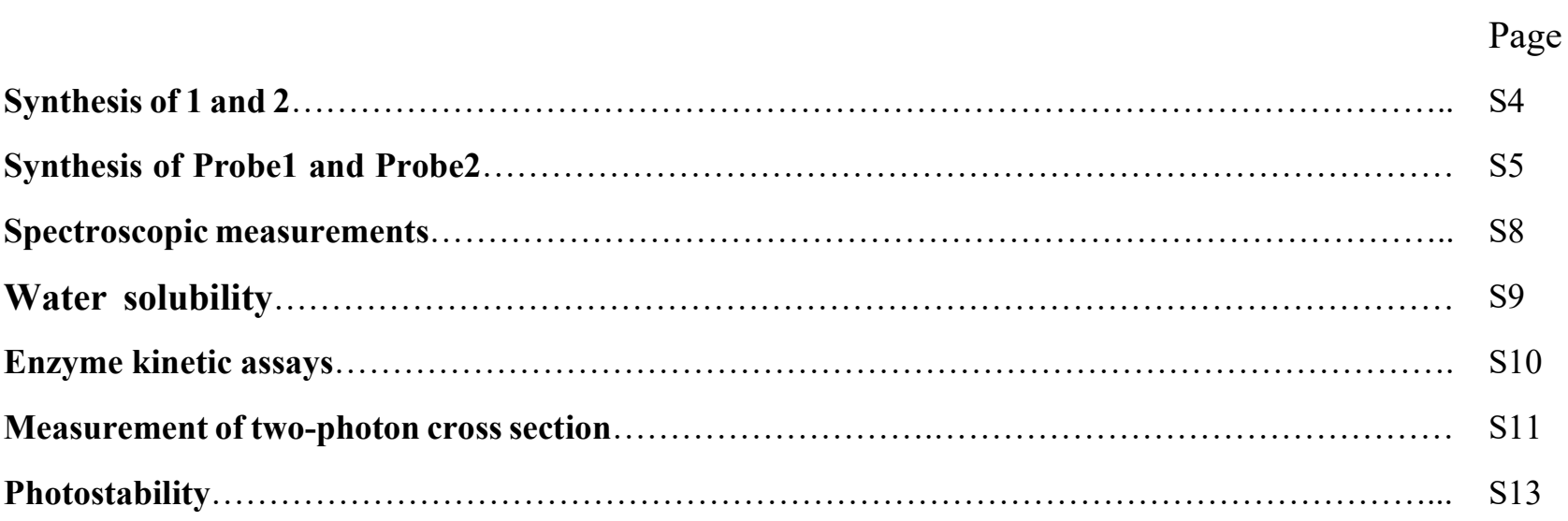

Figure S1. Normalized one-photon absorption and emission spectra of (a) Probe1 and (b) Probe2 in PBS buffer (10 mM, pH 7.4).

Figure S2. One-photon absorption spectra of (a) Probe1 and (c) Probe2 in 10 mM PBS buffer (pH 7.4). Graph of absorbance in different concentration of (b) Probe1 and (d) Probe2.

Figure S3. Kinetics of Probe2 $(0.1-10 \mu \mathrm{M})$ with GGT (100 U/L) in PBS buffer (10 mM, pH 7.4) at 385 nm excitation.

Figure S4. Two-photon action spectra of Probe1, 1, Probe2 and 2 in PBS buffer (10 mM, pH 7.4)

Figure S5. Pseudocolored ratiometric images of (A, B) Chang cells and (C, D) HepG2 cells incubated with Probe2 $(2.0 \mu \mathrm{M})$ for $90 \mathrm{~min}$. DON $(1 \mathrm{mM})$ was pretreated for $1 \mathrm{~h}$ and incubated with Probe2. (E) Average $F_{\text {green }} / F_{\text {blue }}$ intensity ratios. Images were collected at $750 \mathrm{~nm}$ excitation and emission windows of $400-450 \mathrm{~nm}$ (blue) and $500-600 \mathrm{~nm}$ (green). Scale bars, $50 \mu \mathrm{m} n$ is number of counted cells.

Figure S6. (a) TPM images of HeLa cells after staining of Probe2 $(2.0 \mu \mathrm{M})$. (b) Time-dependent twophoton fluorescence intensity of A-C in Figure (a). Detection window of TPEF intensities was 390-700 $\mathrm{nm}$ with femto-second pulses at $750 \mathrm{~nm}$ excitation. Scale bar, $50 \mu \mathrm{m}$.

Figure S7. Pseudocolored images $\left(F_{\text {red }} / F_{\text {orange }}\right)$ of HCT 116 cells incubated with (a) Probe1 $(2.0 \mu \mathrm{M})$ for $90 \mathrm{~min}$ and DON (1.0 mM), (b) Probe1 $(2.0 \mu \mathrm{M})$ for $90 \mathrm{~min}$. HCT 116 cells in a were pretreated with the inhibitor and then incubated with Probe1. $F_{\text {orange }}=520-580 \mathrm{~nm}$ and $F_{\text {red }}=600-670 \mathrm{~nm}$. The excitation wavelength was $750 \mathrm{~nm}$. Scale bar, $50 \mu \mathrm{m}$...

Figure S8. (A) Pseudocolored ratiometric image of human colon cancer tissues incubated with Probe2 $(20 \mu \mathrm{M})$ for 90 min. (B) Enlarged image and (C) Section images within the dotted white box in (A) acquired at depths of 140-200 $\mu \mathrm{m}$. Images were collected at $750 \mathrm{~nm}$ excitation and emission windows of 400-450 nm (blue) and 500-600 nm (green). Scale bars, $150 \mu \mathrm{m}$. 


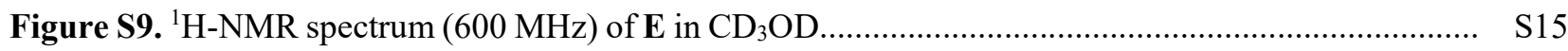

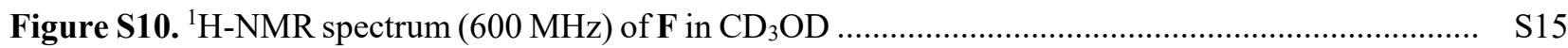

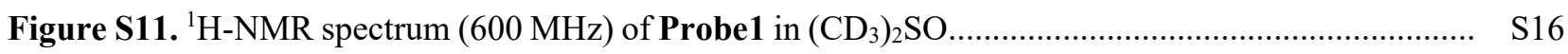

Figure S12. HRMS spectrum of Probe1.................................................................................... S16

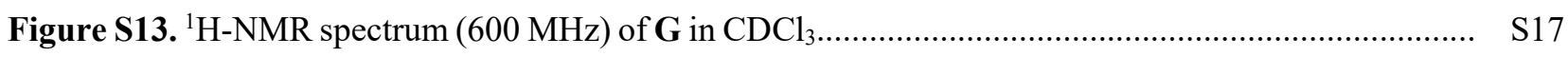

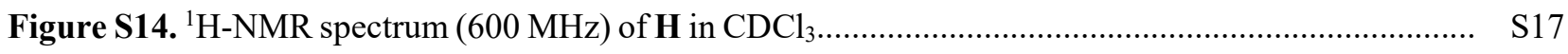

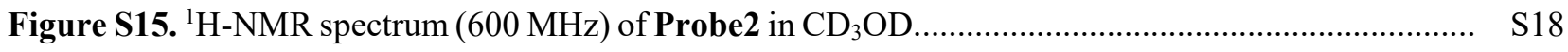

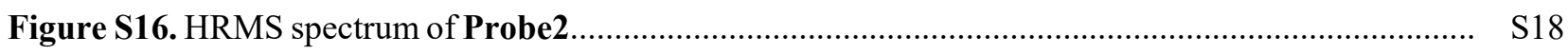

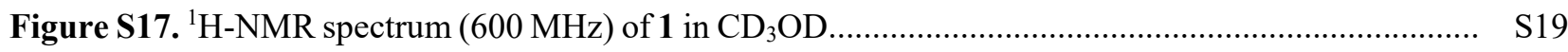

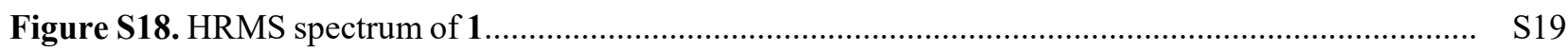

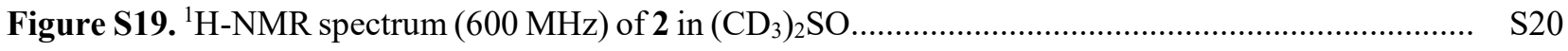

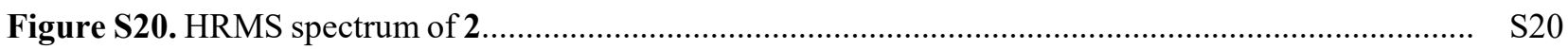

Table S1. Kinetic parameters for Probe2 with GGT …….............................................................. S10 
Synthesis of 1 and 2. Compound $\mathbf{A}, \mathbf{B}$ and $\mathbf{D}$ were prepared by the literature method. ${ }^{1}$

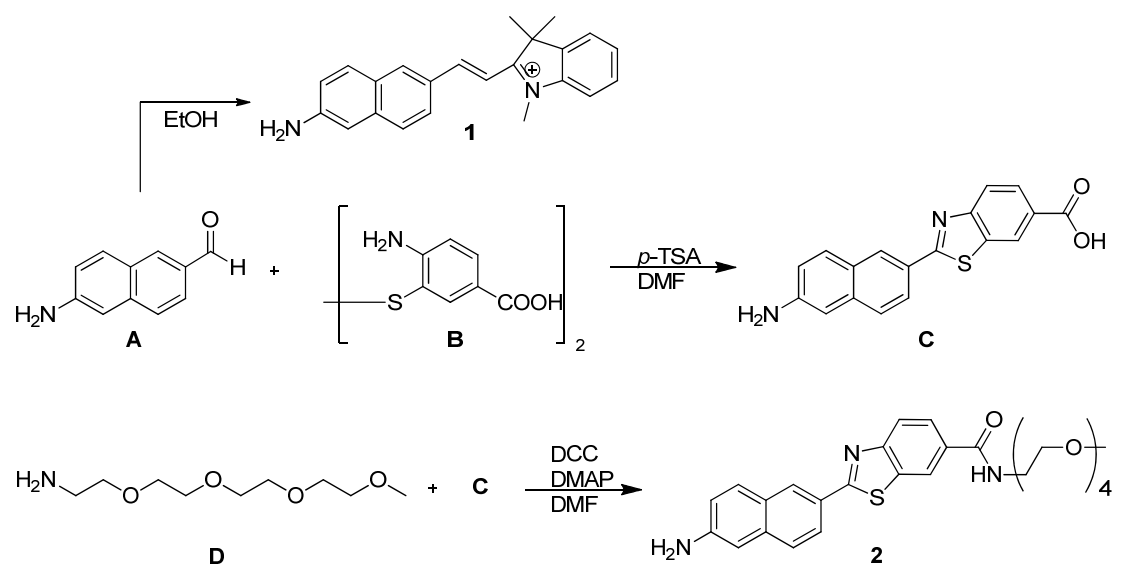

Compound 1 A mixture of $\mathbf{A}(100 \mathrm{mg}, 0.58 \mathrm{mmol})$ and 1,2,3,3-Tetramethyl-3H-indolium iodide (127 mg, 0.73 mmol) was stirred overnight under nitrogen atmosphere at $90{ }^{\circ} \mathrm{C}$. Then reaction mixture was concentrated under reduced pressure and purified with column chromatography (DCM: $\mathrm{MeOH}=95: 5)$, Yield: $80 \mathrm{mg}(38 \%),{ }^{1} \mathrm{H}$ NMR $\left(600 \mathrm{MHz}, \mathrm{CD}_{3} \mathrm{OD}\right) \delta 8.48(\mathrm{~d}, 1 \mathrm{H}, J=16.2 \mathrm{~Hz}), 8.28(\mathrm{~s}, 1 \mathrm{H}), 7.96(\mathrm{dd}, 1 \mathrm{H}, J=2.4 \mathrm{~Hz}, 7.8 \mathrm{~Hz}), 7.60(\mathrm{~d}, 1 \mathrm{H}, J=$ $9 \mathrm{~Hz}), 7.79(\mathrm{~d}, 1 \mathrm{H}, J=9 \mathrm{~Hz}), 7.72(\mathrm{~m}, 2 \mathrm{H}), 7.59(\mathrm{~m}, 3 \mathrm{H}), 7.51(\mathrm{~s}, 1 \mathrm{H}, J=16.2 \mathrm{~Hz}), 7.03(\mathrm{dd}, 1 \mathrm{H}, J=8.4 \mathrm{~Hz}, 2.4$ Hz), $6.92(\mathrm{~d}, 1 \mathrm{H}, J=2.4 \mathrm{~Hz}), 4.09(\mathrm{~s}, 3 \mathrm{H}), 1.84(\mathrm{~s}, 6 \mathrm{H})$. HRMS (ESI+): m/z calculated for $\left[\mathrm{C}_{23} \mathrm{H}_{23} \mathrm{~N}_{2}\right]$ 327.1856, found: 327.1864

Compound C compound A (116 mg, $0.68 \mathrm{mmol}), \mathbf{B}(124 \mathrm{mg}, 0.68 \mathrm{mmol})$ and $p$-TSA was dissolved in DMF. The mixture was refluxed overnight at $80{ }^{\circ} \mathrm{C}$. After evaporation of solvent, the residue was purified with column chromatography (DCM: $\mathrm{MeOH}=95: 5)$ Yield: $22 \mathrm{mg}(10 \%),{ }^{1} \mathrm{H}$ NMR (600 MHz, $\left.\mathrm{CD}_{3} \mathrm{OD}\right) \delta 8.46(\mathrm{~s}, 1 \mathrm{H}), 8.40$ $(\mathrm{s}, 1 \mathrm{H}), 8.14(\mathrm{~d}, 1 \mathrm{H}, J=8.4 \mathrm{~Hz}), 8.01(\mathrm{~d}, 2 \mathrm{H}, J=7.8 \mathrm{~Hz}), 7.68(\mathrm{~d}, 1 \mathrm{H}, J=8.4 \mathrm{~Hz}), 7.64(\mathrm{~d}, 1 \mathrm{H}, J=9 \mathrm{~Hz}), 7.06$ $(\mathrm{d}, 1 \mathrm{H}, J=9 \mathrm{~Hz}), 6.98(\mathrm{~s}, 1 \mathrm{H}), 4.55(\mathrm{~s}, 2 \mathrm{H})$

Compound 2 The compound $\mathbf{C}$ (10 mg, $0.03 \mathrm{mmol}$ ) and 1-Ethyl-3-(3-dimethylaminopropyl)- carbodiimide (EDC) (5.8 mg, $0.03 \mathrm{mmol})$, 4-Dimethylaminopyridine (DMAP) $(5.3 \mathrm{mg}, 0.03 \mathrm{mmol})$ was dissolved in DMF and stirred for 1 hour. Dropwise compound $\mathbf{D}(12.4 \mathrm{mg}, 0.06 \mathrm{mmol})$ dissolved in DMF at room temperature and stirred for 
12 hours. The mixture was concentrated under reduced pressure and extracted with $\mathrm{H}_{2} \mathrm{O} / \mathrm{DCM}$. The organic phase was concentrated under reduced pressure and purified with column chromatography (DCM: $\mathrm{MeOH}=97: 3)$. Yield $6 \mathrm{mg}(40 \%),{ }^{1} \mathrm{H}$ NMR $\left(600 \mathrm{MHz},\left(\mathrm{CD}_{3}\right)_{2} \mathrm{SO}\right) \delta 8.56(\mathrm{~s}, 1 \mathrm{H}), 8.35(\mathrm{~s}, 1 \mathrm{H}), 8.02(\mathrm{~d}, 1 \mathrm{H}, J=8.4 \mathrm{~Hz}), 7.97(\mathrm{~d}, 1 \mathrm{H}, J$ $=9 \mathrm{~Hz}), 7.79(\mathrm{~d}, 1 \mathrm{H}, J=9 \mathrm{~Hz}), 7.60(\mathrm{~d}, 1 \mathrm{H}, J=8.4 \mathrm{~Hz}), 6.98(\mathrm{~d}, 1 \mathrm{H}, J=7.2 \mathrm{~Hz}), 6.82(\mathrm{~s}, 1 \mathrm{H}), 5.81(\mathrm{~s}, 2 \mathrm{H}), 3.53-$ $3.42(\mathrm{~m}, 16 \mathrm{H}), 3.35(\mathrm{~m}, 3 \mathrm{H})$. HRMS (ESI+): $\mathrm{m} / \mathrm{z}$ calculated for $\left[\mathrm{C}_{27} \mathrm{H}_{32} \mathrm{O}_{5} \mathrm{~N}_{3} \mathrm{~S}\right]^{+}: 510.2057$, found: 510.2069

\section{Synthesis of Probe1 and Probe2}
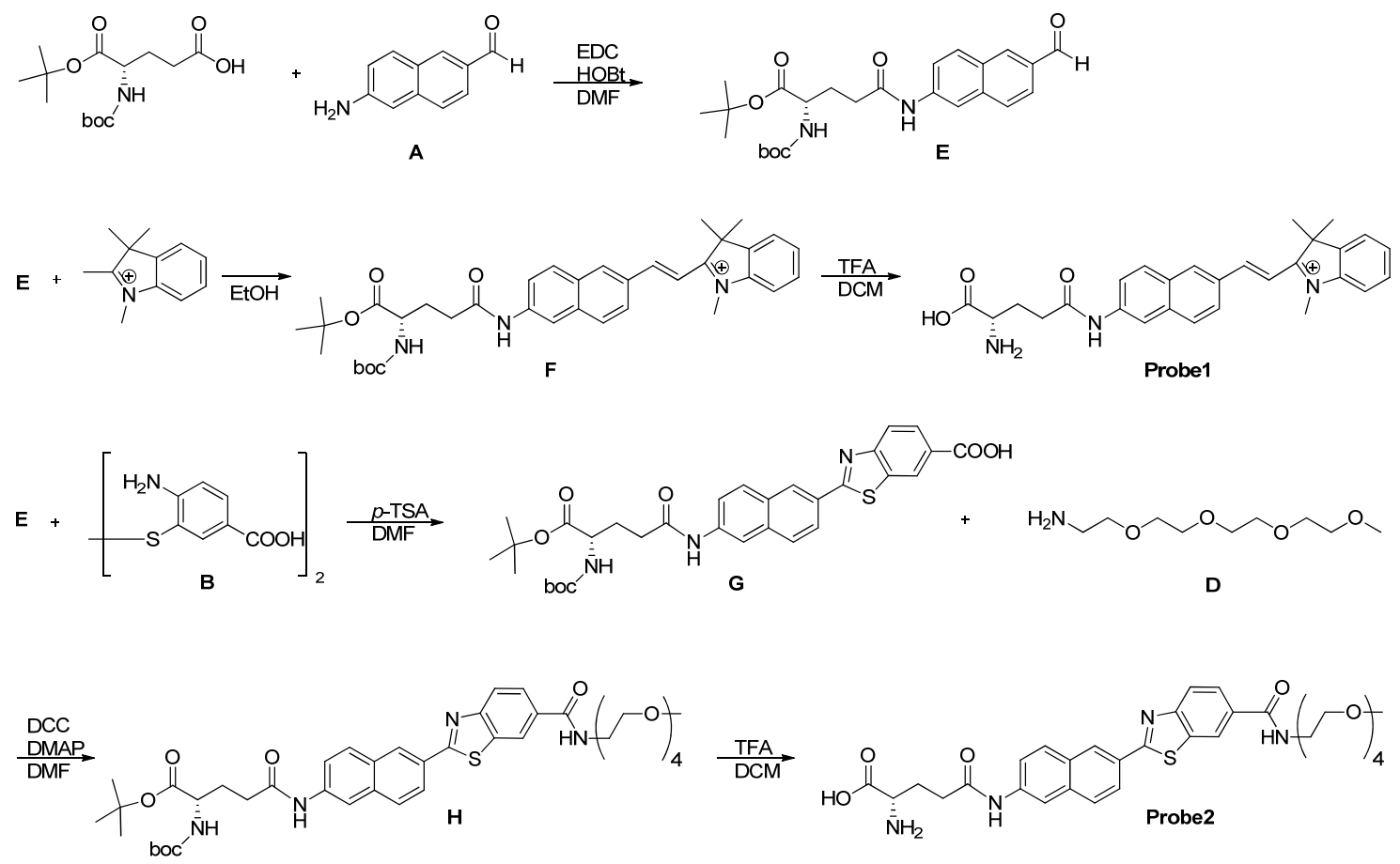

Compound E The mixture of N-Boc-Glu-OtBu (1.0 g, $3.29 \mathrm{mmol})$ and 1-Ethyl-3-(3-dimethylaminopropyl)carbodiimide (EDC) (830 mg, $4.33 \mathrm{mmol})$, Hydroxybenzotriazole (HOBt) (1.3 g, $8.49 \mathrm{mmol})$ was dissolved in Dimethylformamide (DMF) (3 mL) and stirred it for 1 hour. Dropwise the compound A (500 mg, $2.92 \mathrm{mmol})$ dissolved in DMF into the flask and stirred it overnight at $70{ }^{\circ} \mathrm{C}$. The mixture was concentrated in reduced pressure and extract with $\mathrm{H}_{2} \mathrm{O} / \mathrm{DCM}$. The organic phase was concentrated under reduced pressure and purified with column 
chromatography $\left(\mathrm{CHCl}_{3}: \mathrm{MeOH}=98: 2\right)$. Yield: $675 \mathrm{mg}(65 \%),{ }^{1} \mathrm{H}$ NMR $\left(600 \mathrm{MHz}, \mathrm{CD}_{3} \mathrm{OD}\right) \delta 10.01(\mathrm{~s}, 1 \mathrm{H})$, $8.30(\mathrm{~d}, 1 \mathrm{H}, J=13.8 \mathrm{~Hz}), 7.93(\mathrm{~d}, 1 \mathrm{H}, J=9 \mathrm{~Hz}), 7.83(\mathrm{~m}, 3 \mathrm{H}), 7.63(\mathrm{~d}, 1 \mathrm{H}, J=7.8 \mathrm{~Hz}), 4.10(\mathrm{~m}, 1 \mathrm{H}), 2.52(\mathrm{~m}$, $1 \mathrm{H}), 2.20(\mathrm{~m}, 1 \mathrm{H}), 1.98(\mathrm{~m}, 1 \mathrm{H}), 1.46(\mathrm{~s}, 9 \mathrm{H}), 1.40(\mathrm{~s}, 9 \mathrm{H})$

Compound F The mixture of $\mathbf{E}$ (300 $\mathrm{mg}, 0.84 \mathrm{mmol}$ ) and 1,2,3,3-Tetramethyl-3H-indolium iodide (147 $\mathrm{mg}, 0.84$ mmol) was stirred overnight. The mixture was concentrated in reduced pressure and purified with column chromatography (DCM: $\mathrm{MeOH}=95: 5)$. Yield $103 \mathrm{mg}(20 \%){ }^{1} \mathrm{H}$ NMR $\left(600 \mathrm{MHz}, \mathrm{CD}_{3} \mathrm{OD}\right) \delta 8.55(\mathrm{~d}, 1 \mathrm{H}, J=$ $16.2 \mathrm{~Hz}), 8.45(\mathrm{~s}, 1 \mathrm{H}), 8.37(\mathrm{~s}, 1 \mathrm{H}), 8.13(\mathrm{~d}, 1 \mathrm{H}, J=8.4 \mathrm{~Hz}), 7.97(\mathrm{~d}, 1 \mathrm{H}, J=9 \mathrm{~Hz}), 7.90(\mathrm{~d}, 1 \mathrm{H}, J=9 \mathrm{~Hz}), 7.81$ (m, 1H), $7.76(\mathrm{~m}, 1 \mathrm{H}), 7.73(\mathrm{~s}, 1 \mathrm{H}), 7.70(\mathrm{~s}, 1 \mathrm{H}), 7.66(\mathrm{~d}, 1 \mathrm{H}, J=9 \mathrm{~Hz}), 7.42(\mathrm{t}, 1 \mathrm{H}, J=6.6 \mathrm{~Hz}), 4.21(\mathrm{~s}, 1 \mathrm{H})$, $4.09(\mathrm{q}, 1 \mathrm{H}, J=4.8 \mathrm{~Hz}), 2.58(\mathrm{t}, 2 \mathrm{H}, J=7.2 \mathrm{~Hz}), 2.23(\mathrm{~m}, 1 \mathrm{H}), 2.01(\mathrm{~m}, 1 \mathrm{H}), 1.90(\mathrm{~s}, 1 \mathrm{H}), 1.49(\mathrm{~s}, 9 \mathrm{H}), 1.42(\mathrm{~s}$, 9H)

Probe1 Compound F (50 mg, $0.082 \mathrm{mmol})$ was dissolved in DCM $(1 \mathrm{~mL})$ and stirred for $30 \mathrm{~min}$. TFA $(1 \mathrm{~mL})$ was added at $0{ }^{\circ} \mathrm{C}$ and the mixture was stirred overnight. The mixture was concentrated in reduced pressure and recrystalized with acetone. Yield $15 \mathrm{mg}(40 \%){ }^{1} \mathrm{H}$ NMR $\left(600 \mathrm{MHz},\left(\mathrm{CD}_{3}\right)_{2} \mathrm{SO}\right) \delta 10.68(\mathrm{~s}, 1 \mathrm{H}) 8.62(\mathrm{~s}, 1 \mathrm{H}), 8.53$ $(\mathrm{d}, 1 \mathrm{H}, J=16.2 \mathrm{~Hz}), 8.41(\mathrm{~s}, 1 \mathrm{H}), 8.28(\mathrm{~d}, 1 \mathrm{H}, J=8.4 \mathrm{~Hz}), 7.95(\mathrm{~d}, 2 \mathrm{H}, J=7.8 \mathrm{~Hz}), 7.86(\mathrm{~m}, 2 \mathrm{H}), 7.72(\mathrm{~d}, 1 \mathrm{H}, J$ $=16.2 \mathrm{~Hz}), 7.67(\mathrm{~d}, 1 \mathrm{H}, J=9 \mathrm{~Hz}), 7.60(\mathrm{~m}, 2 \mathrm{H}), 5.19(\mathrm{s.} 3 \mathrm{H}), 4.14(\mathrm{~s}, 3 \mathrm{H}), 3.99(\mathrm{q}, 1 \mathrm{H}, J=7.2 \mathrm{~Hz}), 2.58(\mathrm{~m}, 2 \mathrm{H})$, $2.02(\mathrm{~m}, 2 \mathrm{H}), 1.79(\mathrm{~s}, 6 \mathrm{H})$. HRMS (ESI+): $\mathrm{m} / \mathrm{z}$ calculated for $\left[\mathrm{C}_{28} \mathrm{H}_{30} \mathrm{O}_{3} \mathrm{~N}_{3}\right]: 456.2293$ and found 456.2282

Compound G Compound E (300 mg, $0.84 \mathrm{mmol})$, B (154 mg, $0.84 \mathrm{mmol})$ and $p$-TSA was dissolved in DMF. The mixture was refluxed and stirred overnight at $80{ }^{\circ} \mathrm{C}$. After evaporation of solvent, the residue was purified with column chromatography (DCM: $\mathrm{MeOH}=97: 3)$, Yield $66 \mathrm{mg}(13 \%){ }^{1} \mathrm{H} \mathrm{NMR}\left(600 \mathrm{MHz}, \mathrm{CDCl}_{3}\right) \delta 8.55(\mathrm{~s}$, 1H), $8.40(\mathrm{~s}, 1 \mathrm{H}), 8.27(\mathrm{~s}, 1 \mathrm{H}), 8.09(\mathrm{~d}, 1 \mathrm{H}, J=7.8 \mathrm{~Hz}), 8.02(\mathrm{~d}, 1 \mathrm{H}, J=8.4 \mathrm{~Hz}), 7.99(\mathrm{~d}, 1 \mathrm{H}, J=7.2 \mathrm{~Hz}) 7.82$ (s, 2H), $7.51(\mathrm{t}, 1 \mathrm{H}, J=7.2 \mathrm{~Hz}), 4.12(\mathrm{~d}, 1 \mathrm{H}, J=5.4 \mathrm{~Hz}), 2.44(\mathrm{~d}, 2 \mathrm{H}, J=5.4 \mathrm{~Hz}), 2.20(\mathrm{~m}, 2 \mathrm{H}), 1.40(\mathrm{~s}, 9 \mathrm{H})$, $1.39(\mathrm{~s}, 9 \mathrm{H})$ 
Compound H The mixture of $\mathbf{G}(110 \mathrm{mg}, 0.22 \mathrm{mmol})$ and $N, N^{\prime}$-Dicyclohexylcarbodiimide (DCC) (68 mg, 0.33 mmol), and Hydroxybenzotriazole (HOBt) (46 mg, $0.44 \mathrm{mmol}$ ) was stirred for 1 hour. Compound $\mathbf{D}$ (45 mg, 0.22 mmol) was slowly added and stirred overnight at room temperature. The mixture was concentrated in reduced vacuum and added $\mathrm{MeCN}$. The solid was removed and the residue was concentrated in reduced vacuum and purified with column chromatography $\left(\mathrm{CHCl}_{3}: \mathrm{MeOH}=97: 3\right)$, Yield $60 \mathrm{mg}(40 \%),{ }^{1} \mathrm{H} \mathrm{NMR}\left(600 \mathrm{MHz}, \mathrm{CDCl}_{3}\right)$ $\delta 8.54(\mathrm{~s}, 1 \mathrm{H}), 8.41(\mathrm{~d}, 2 \mathrm{H}, J=7.2 \mathrm{~Hz}), 8.24(\mathrm{~s}, 1 \mathrm{H}), 8.06(\mathrm{~d}, 1 \mathrm{H}, J=8.4 \mathrm{~Hz}), 7.98(\mathrm{~d}, 1 \mathrm{H}, J=8.4 \mathrm{~Hz}), 7.91(\mathrm{~d}$, $1 \mathrm{H}, J=9 \mathrm{~Hz}), 7.81(\mathrm{~d}, 1 \mathrm{H}, J=9 \mathrm{~Hz}), 7.57(\mathrm{dd}, 1 \mathrm{H}, J=1.2 \mathrm{~Hz}, 9 \mathrm{~Hz}), 6.89(\mathrm{~d}, 1 \mathrm{H}, J=7.8 \mathrm{~Hz}), 4.06(\mathrm{q}, 1 \mathrm{H}, J=$ $7.8 \mathrm{~Hz}), 3.68-3.56(\mathrm{~m}, 16 \mathrm{H}), 3.44(\mathrm{~m}, 3 \mathrm{H}), 2.53(\mathrm{~m}, 2 \mathrm{H}), 2.20(\mathrm{~m}, 1 \mathrm{H}), 1.99(\mathrm{~m}, 1 \mathrm{H}), 1.46(\mathrm{~s}, 9 \mathrm{H}), 1.44(\mathrm{~s}, 9 \mathrm{H})$

Probe2 Compound $\mathbf{H}(25 \mathrm{mg}, 0.05 \mathrm{mmol})$ was dissolved in DCM (1 mL) and stirred for 30min. TFA (1 mL) was added at $0{ }^{\circ} \mathrm{C}$ and the mixture was stirred overnight. The mixture was concentrated in reduced pressure and recrystalized with acetone. Yield $10 \mathrm{mg}(40 \%){ }^{1} \mathrm{H}$ NMR $\left(600 \mathrm{MHz}, \mathrm{CD}_{3} \mathrm{OD}\right) \delta 8.38(\mathrm{~d}, 2 \mathrm{H}, J=13.8 \mathrm{~Hz}), 8.24(\mathrm{~d}$, $1 \mathrm{H}, J=12 \mathrm{~Hz}), 8.04(\mathrm{~d}, 1 \mathrm{H}, J=9 \mathrm{~Hz}), 7.98(\mathrm{~m}, 1 \mathrm{H}), 7.91(\mathrm{dd}, 1 \mathrm{H}, J=3.6 \mathrm{~Hz}, 8.4 \mathrm{~Hz}), 7.87(\mathrm{~d}, 1 \mathrm{H}, J=7.2 \mathrm{~Hz})$, $7.79(\mathrm{~d}, 1 \mathrm{H}, J=9 \mathrm{~Hz}), 7.57(\mathrm{~m}, 1 \mathrm{H}), 4.12(\mathrm{q}, 1 \mathrm{H}, J=6.5 \mathrm{~Hz}), 3.62-3.52(\mathrm{~m}, 16 \mathrm{H}), 3.45(\mathrm{~m}, 3 \mathrm{H}), 2.74(\mathrm{~m}, 2 \mathrm{H})$, $2.29(\mathrm{~m}, 2 \mathrm{H}) \mathrm{HRMS}(\mathrm{ESI}+)$ : $\mathrm{m} / \mathrm{z}$ calculated for $\left[\mathrm{C}_{32} \mathrm{H}_{39} \mathrm{O}_{8} \mathrm{~N}_{4} \mathrm{~S}\right]: 639.2483$ found 639.2500 
Spectroscopic measurements Absorption spectra were recorded on a S-3100 UV-Vis spectrophotometer and fluorescence spectra were obtained with FluoroMate FS-2 fluorescence spectrophotometer with a $1 \mathrm{~cm}$ standard quartz cell. The fluorescence quantum yield was determined by using Rhodamine $(\Phi=0.95$ in $\mathrm{MeOH})$ for Probe1 and 9, 10-diphenylanthrancene $(\Phi=0.93$ in cyclohexane) for Probe2 as the reference by the literature method. ${ }^{2,3}$
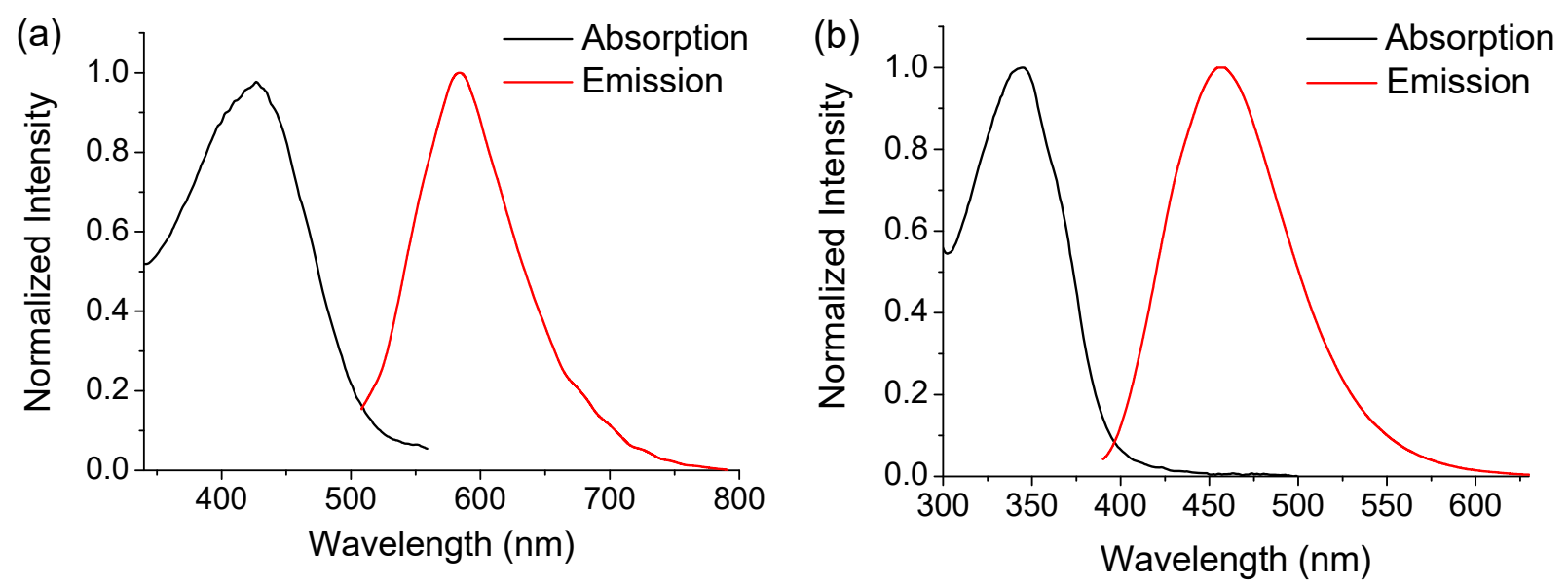

Figure S1. Normalized one-photon absorption and emission spectra of (a) Probe1 and (b) Probe2 in PBS buffer (10 mM, pH 7.4). 
Water solubility Small amount of each probe was dissolved in DMSO to prepare the stock solutions $\left(1.0 \times 10^{-2} \mathrm{M}\right)$. The solution was diluted to $1.0 \times 10^{-5} \sim 0.1 \times 10^{-6} \mathrm{M}$ and added to a cuvette containing $3.0 \mathrm{~mL}$ of PBS buffer (10 mM, pH 7.4). In all cases, the concentration of DMSO in buffer was maintained to be $0.1 \%{ }^{4}$ The plot of absorbance against the dye concentration were linear at low concentration and showed downward curvature at higher concentration (Figure S2). The maximum concentration in the linear region was taken as the solubility. The solubility of Probe1 was $1.0 \mu \mathrm{M}$ and that of Probe2 was $2.0 \mu \mathrm{M}$ in PBS buffer
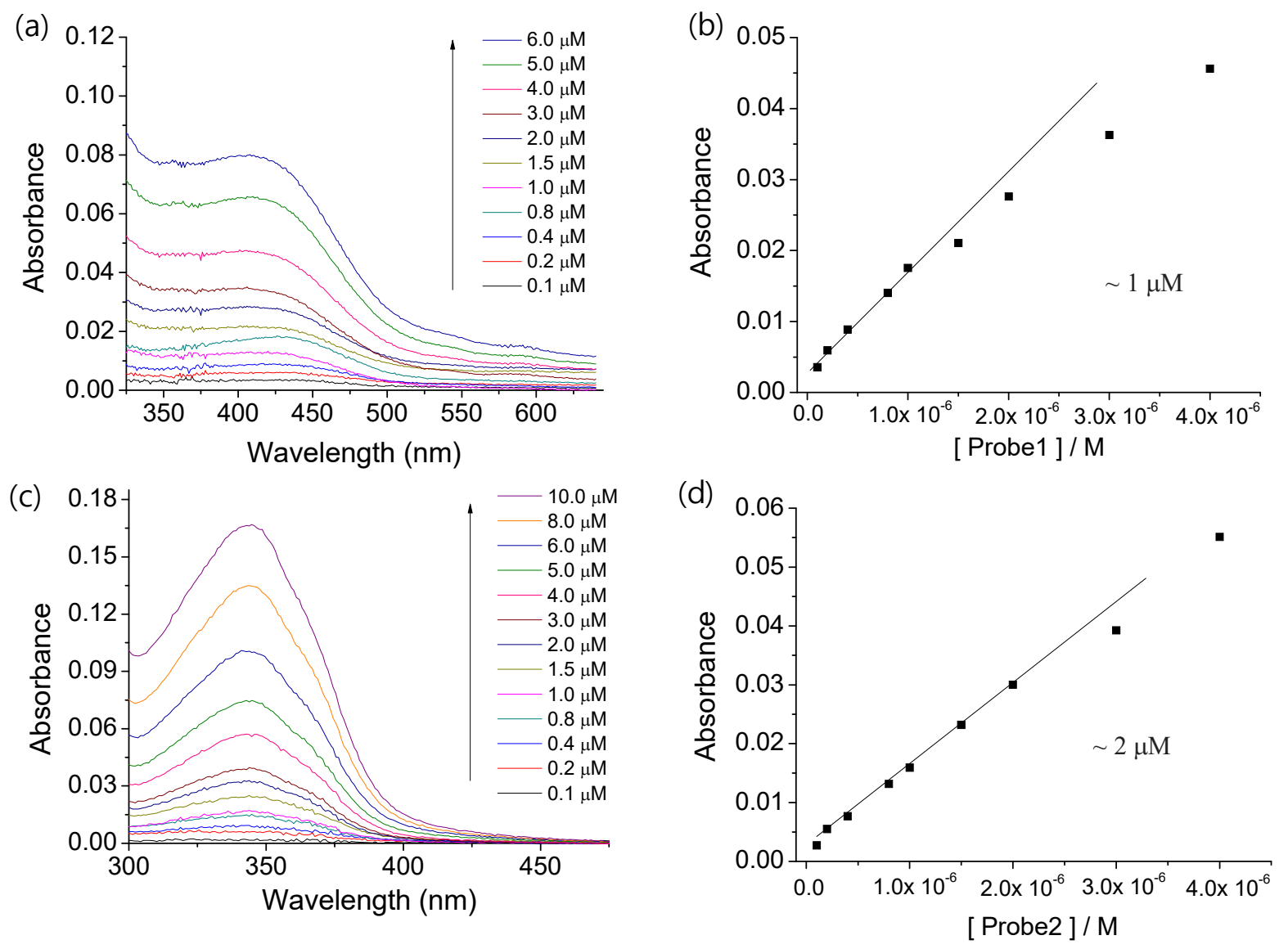

Figure S2. One-photon absorption spectra of (a) Probe1 and (c) Probe2 in $10 \mathrm{mM}$ PBS buffer (pH 7.4). Graph of absorbance in different concentration of (b) Probe1 and (d) Probe2. 
Enzyme kinetic assays Enzymatic kinetic experiments were investigated using a Varioskan Flash micro plate reader (6-1536 well) with a 96-well plate. Various concentrations of Probe2 $(0.1-10 \mu \mathrm{M})$ were prepared in PBS buffer solution $(10 \mathrm{mM}, \mathrm{pH}=7.4)$. $\gamma$-Glutamyltransferase was added to a final concentration of $100 \mathrm{U} / \mathrm{L}$, the fluorescence intensity was collected at $465 \mathrm{~nm}$ for Probe2 $\left(\lambda_{\mathrm{ex}}=385 \mathrm{~nm}\right)$ with 60 second intervals from 0 to $30 \mathrm{~min}$ at $37^{\circ} \mathrm{C}$. The kinetic parameters of Michaelis-Menten equation were calculated with hyperbolic function by the nonlinear fitting algorithm (OriginPro 8.0). Kinetic parameter for Probe1 was not determined because of very weak fluorescence in PBS buffer.

Table S1. Kinetic parameters for Probe2 with GGT

\begin{tabular}{ccccc}
\hline Compound & $K_{m}(\mu \mathrm{M})$ & $k_{c a t}\left(\mathrm{~ms}^{-1}\right)$ & $k_{c a t} / K_{m}\left(\mathrm{M}^{-1} \mathrm{~s}^{-1}\right)$ & $V_{\max }\left(\mu \mathrm{M} \mathrm{s}^{-1}\right)$ \\
\hline Probe1 & n.d. $^{\mathrm{a}}$ & n.d. $^{\mathrm{a}}$ & n.d. $^{\mathrm{a}}$ & n.d. $^{\mathrm{a}}$ \\
\hline Probe2 & 1.37 & 0.607 & $4.43 \times 10^{2}$ & 1.05 \\
\hline
\end{tabular}

a) Not determined.

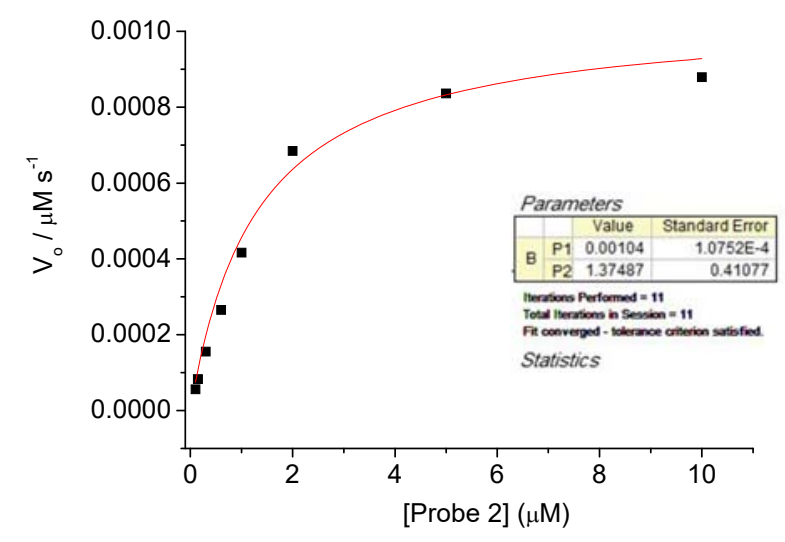

Figure S3. Kinetics of Probe2 $(0.1-10 \mu \mathrm{M})$ with GGT (100 U/L) in PBS buffer (10 mM, pH 7.4) at $385 \mathrm{~nm}$ excitation. 
Measurement of two-photon cross section. The two-photon cross section $(\delta)$ was determined by using femto second (fs) fluorescence measurement technique. ${ }^{5}$ Probe1 $\left(1.0 \times 10^{-6} \mathrm{M}\right)$ and Probe2 $\left(1.0 \times 10^{-6}\right.$ M) was dissolved in PBS buffer $(10 \mathrm{mM}, \mathrm{pH}=7.4)$ respectively and the two-photon induced fluorescence intensity was measured at 760-1020 nm (Probe1) and 700-890 nm (Probe2) using rhodamine 6G as the reference, whose two-photon property has been well characterized in the literature. ${ }^{6}$ The intensities of the two-photon induced fluorescence spectra of the reference and sample emitted at the same excitation wavelength were determined. The TPA cross section was calculated by using $\delta=\delta_{\mathrm{r}}\left(\mathrm{S}_{\mathrm{s}} \Phi_{\mathrm{r}} \varphi_{\mathrm{r}} \mathrm{c}_{\mathrm{r}}\right) /\left(\mathrm{S}_{\mathrm{r}} \Phi_{\mathrm{s}} \varphi_{\mathrm{s}} \mathrm{c}_{\mathrm{s}}\right)$ : where the subscripts $\mathrm{s}$ and $\mathrm{r}$ stand for the sample and reference molecules. The intensity of the signal collected by a CCD detector was denoted as S. $\Phi$ is the fluorescence quantum yield. $\varphi$ is the overall fluorescence collection efficiency of the experimental apparatus. The number density of the molecules in solution was denoted as c. $\delta_{\mathrm{r}}$ is the TPA cross section of the reference molecule.
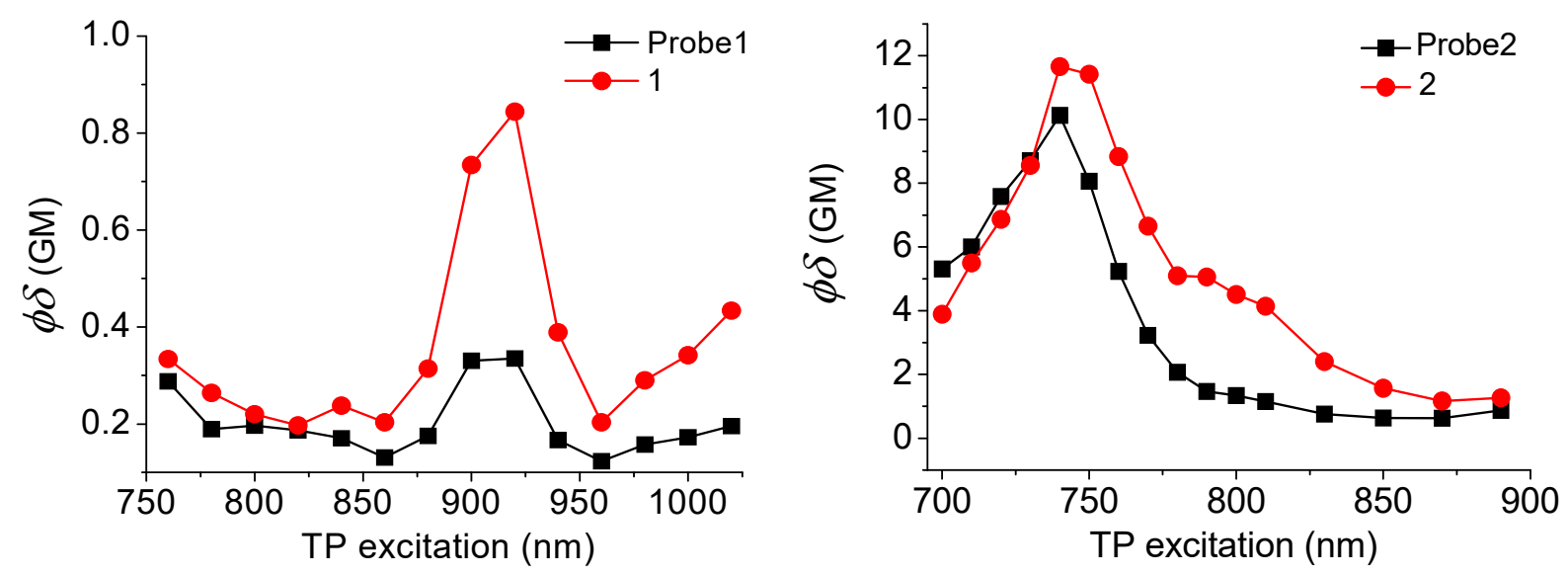

Figure S4. Two-photon action spectra of Probe1, 1, Probe2 and 2 in PBS buffer (10 mM, pH 7.4). 

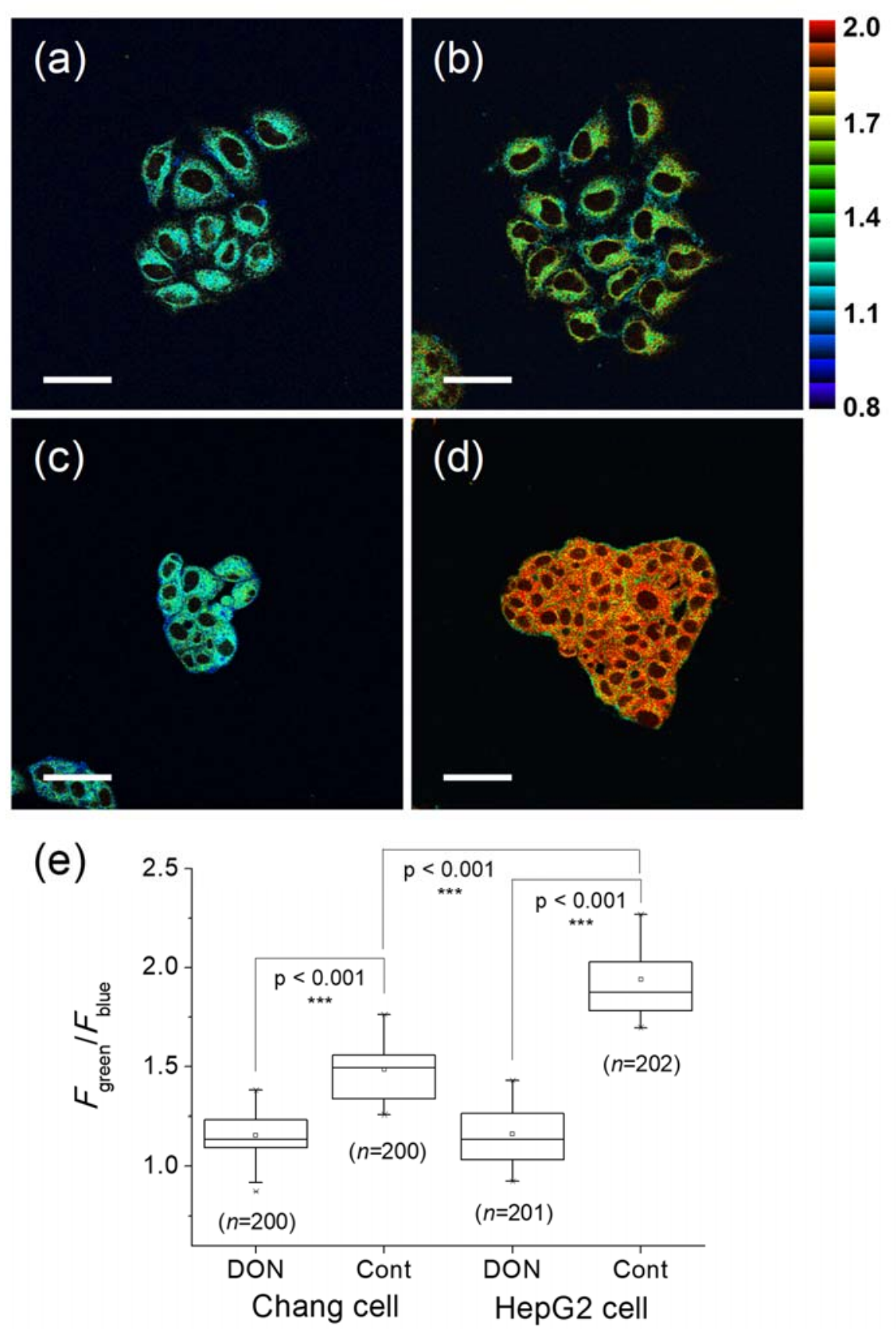

Figure S5. Pseudocolored ratiometric images of (a, b) Chang cells and (c, d) HepG2 cells incubated with Probe2 $(2.0 \mu \mathrm{M})$ for $90 \mathrm{~min}$. DON $(1 \mathrm{mM})$ was pretreated for $1 \mathrm{~h}$ and incubated with Probe2. (e) Average $F_{\text {green }} / F_{\text {blue }}$ intensity ratios. Images were collected at $750 \mathrm{~nm}$ excitation and emission windows of 400-450 nm (blue) and 500$600 \mathrm{~nm}$ (green). Scale bars, $50 \mu \mathrm{m} . n$ is number of counted cells. 
Photostability. Photostability of Probe2 was determined by monitoring the changes in two-photon emission fluorescence (TPEF) intensity with time at three designated positions of Probe2 $(2.0 \mu \mathrm{M})$ in PBS buffer (10 mM, pH 7.4). The TPEF intensity of Probe 2 remained nearly the same for $30 \mathrm{~min}$, indicating high photostability.
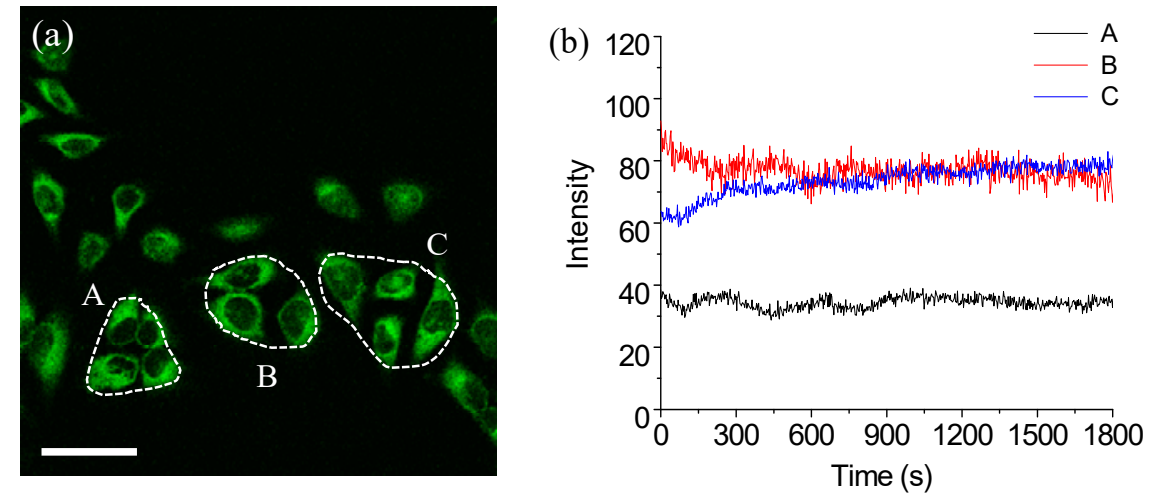

Figure S6. (a) TPM images of HeLa cells after staining of Probe2 $(2.0 \mu \mathrm{M})$. (b) Time-dependent two-photon fluorescence intensity of A-C in Figure (a). Detection window of TPEF intensities was 390-700 nm with femtosecond pulses at $750 \mathrm{~nm}$ excitation. Scale bar, $50 \mu \mathrm{m}$.

\section{Two-photon microscopy images in HCT116 with Probe1}

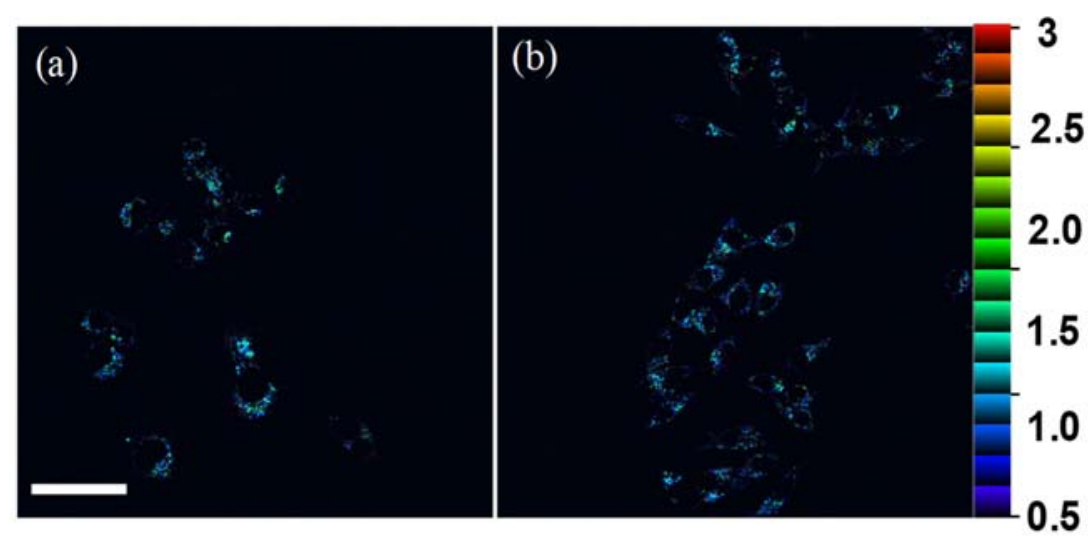

Figure S7. Pseudocolored images $\left(F_{\text {red }} / F_{\text {orange }}\right)$ of HCT 116 cells incubated with (a) Probe1 $(2.0 \mu \mathrm{M})$ for $90 \mathrm{~min}$ and DON (1.0 mM), (b) Probe1 $(2.0 \mu \mathrm{M})$ for $90 \mathrm{~min}$. HCT 116 cells in a were pretreated with the inhibitor and then incubated with Probe1. $F_{\text {orange }}=520-580 \mathrm{~nm}$ and $F_{\text {red }}=600-670 \mathrm{~nm}$. The excitation wavelength was $750 \mathrm{~nm}$. Scale bar, $50 \mu \mathrm{m}$. 

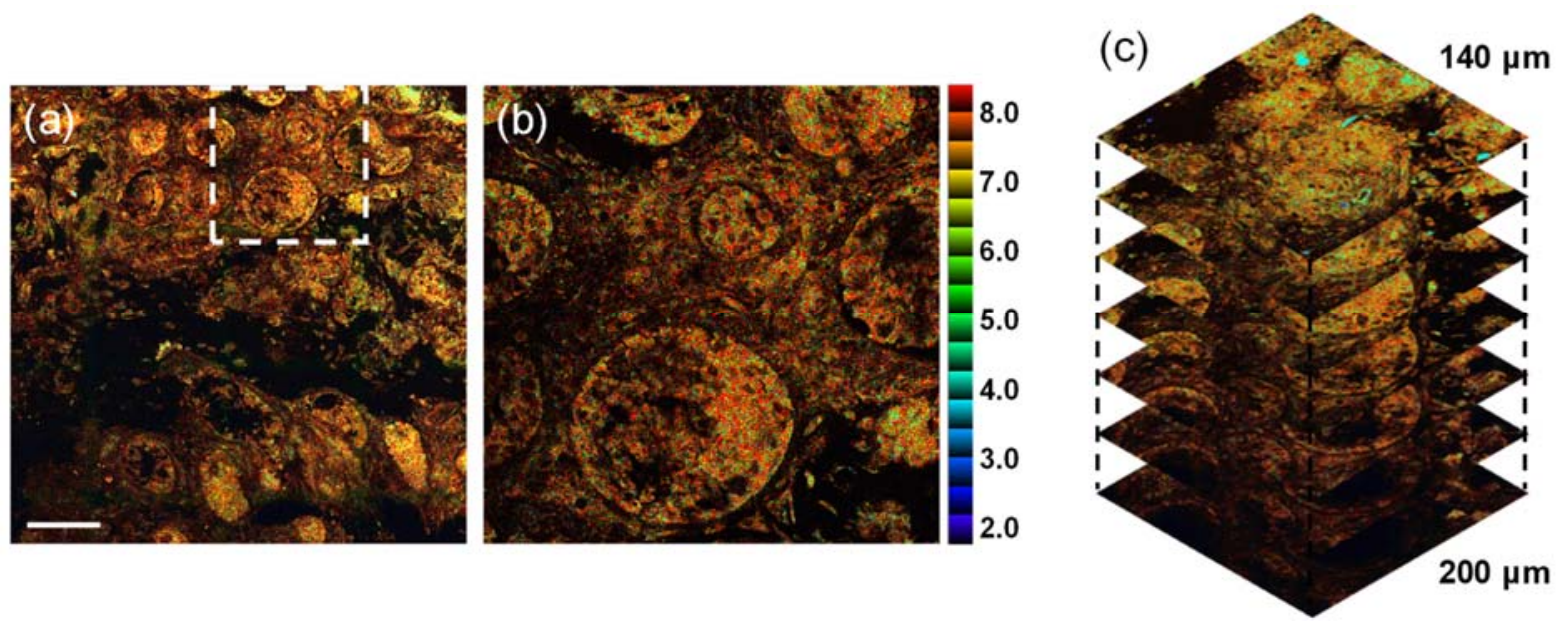

Figure S8. (a) Pseudocolored ratiometric image of human colon cancer tissues incubated with Probe2 $(20 \mu \mathrm{M})$ for $90 \mathrm{~min}$. (b) Enlarged image and (c) Section images within the dotted white box in (A) acquired at depths of 140-200 $\mu \mathrm{m}$. Images were collected at $750 \mathrm{~nm}$ excitation and emission windows of 400-450 nm (blue) and 500$600 \mathrm{~nm}$ (green). Scale bars, $150 \mu \mathrm{m}$. 


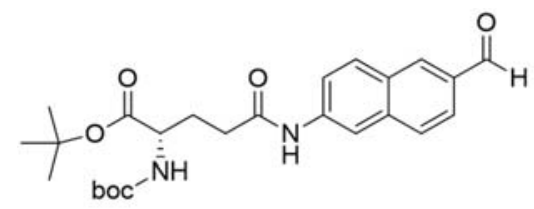

Figure S9. ${ }^{1} \mathrm{H}-\mathrm{NMR}$ spectrum $(600 \mathrm{MHz})$ of $\mathbf{E}$ in $\mathrm{CD}_{3} \mathrm{OD}$
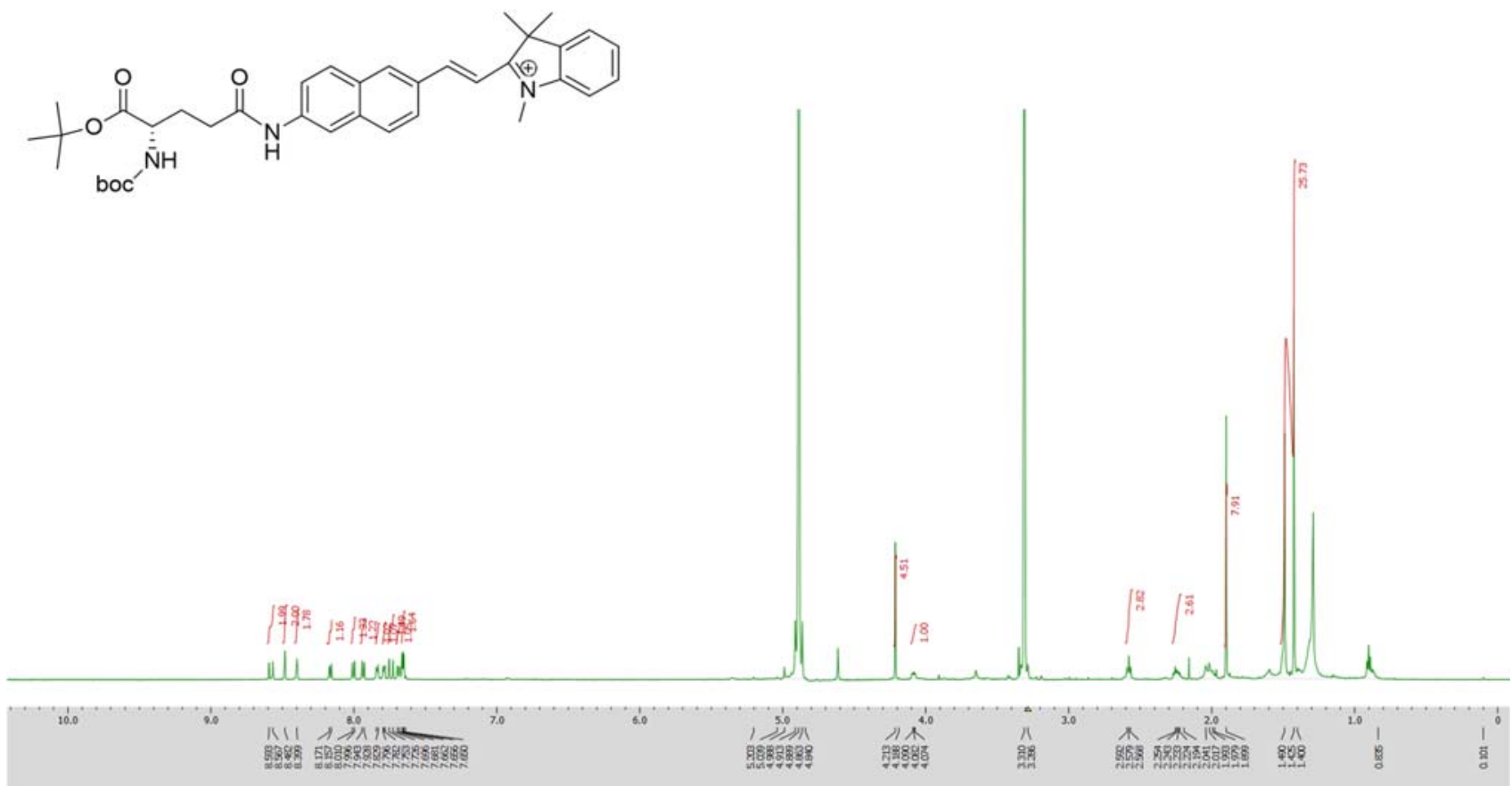

Figure S10. ${ }^{1} \mathrm{H}-\mathrm{NMR}$ spectrum $(600 \mathrm{MHz})$ of $\mathbf{F}$ in $\mathrm{CD}_{3} \mathrm{OD}$ 
<smiles>CN1CC(C=Cc2ccc3cc(NC(=O)CC[C@H]([NH3+])C(=O)O)ccc3c2)C(C)(C)c2ccccc21</smiles>

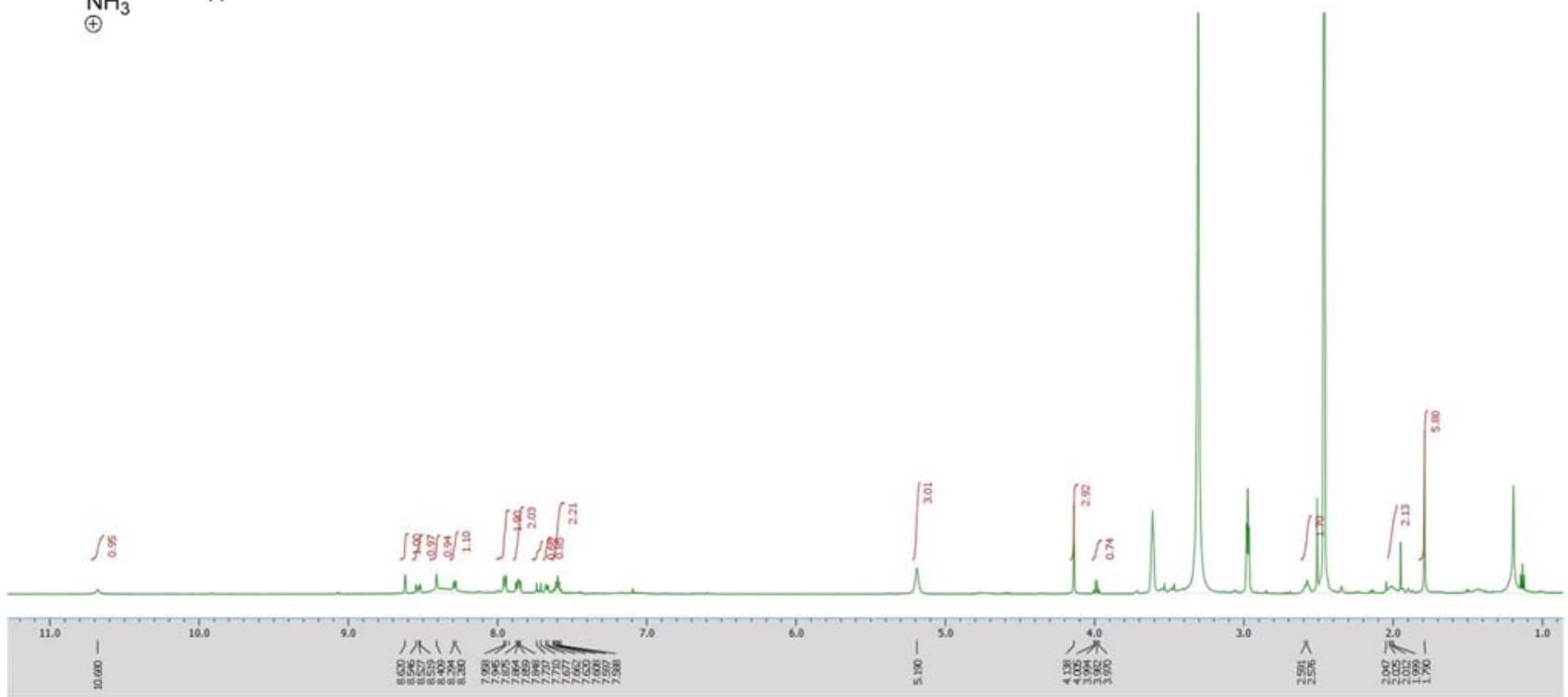

Figure S11. ${ }^{1} \mathrm{H}-\mathrm{NMR}$ spectrum $(600 \mathrm{MHz})$ of Probe1 in $\left(\mathrm{CD}_{3}\right)_{2} \mathrm{SO}$

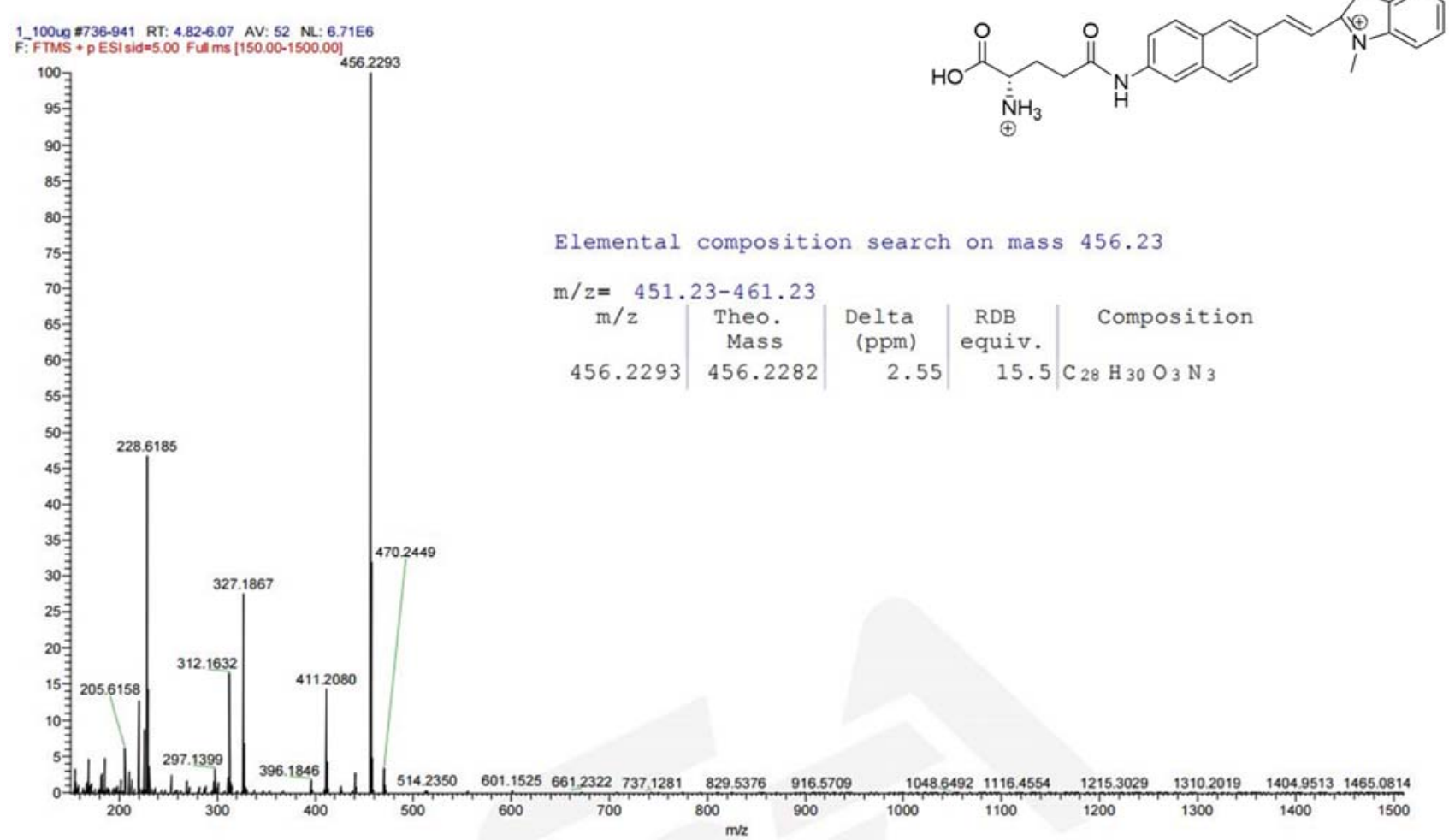

Figure S12. HRMS spectrum of Probe1 

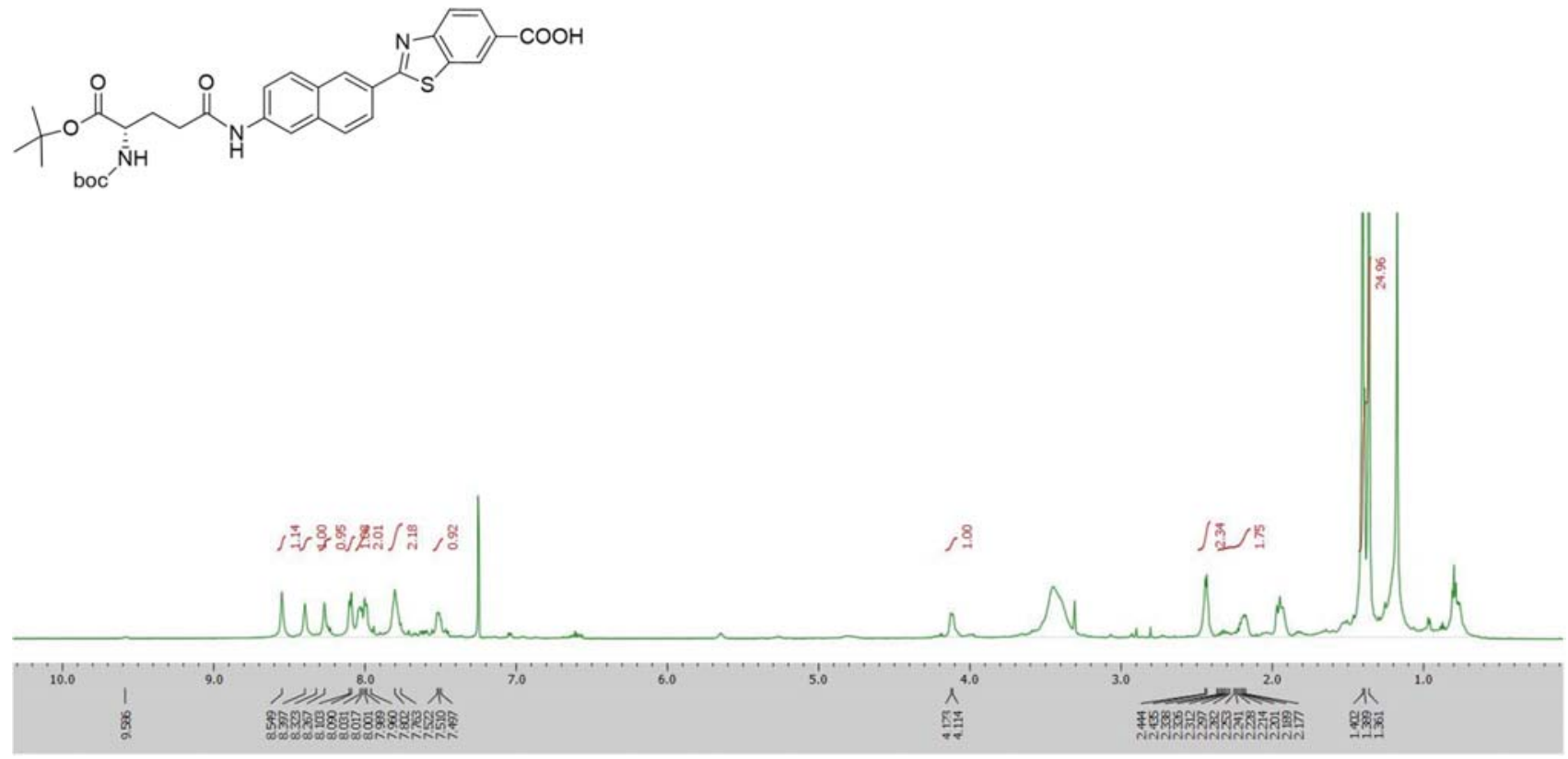

Figure S13. ${ }^{1} \mathrm{H}-\mathrm{NMR}$ spectrum $(600 \mathrm{MHz})$ of $\mathbf{G}$ in $\mathrm{CDCl}_{3}$
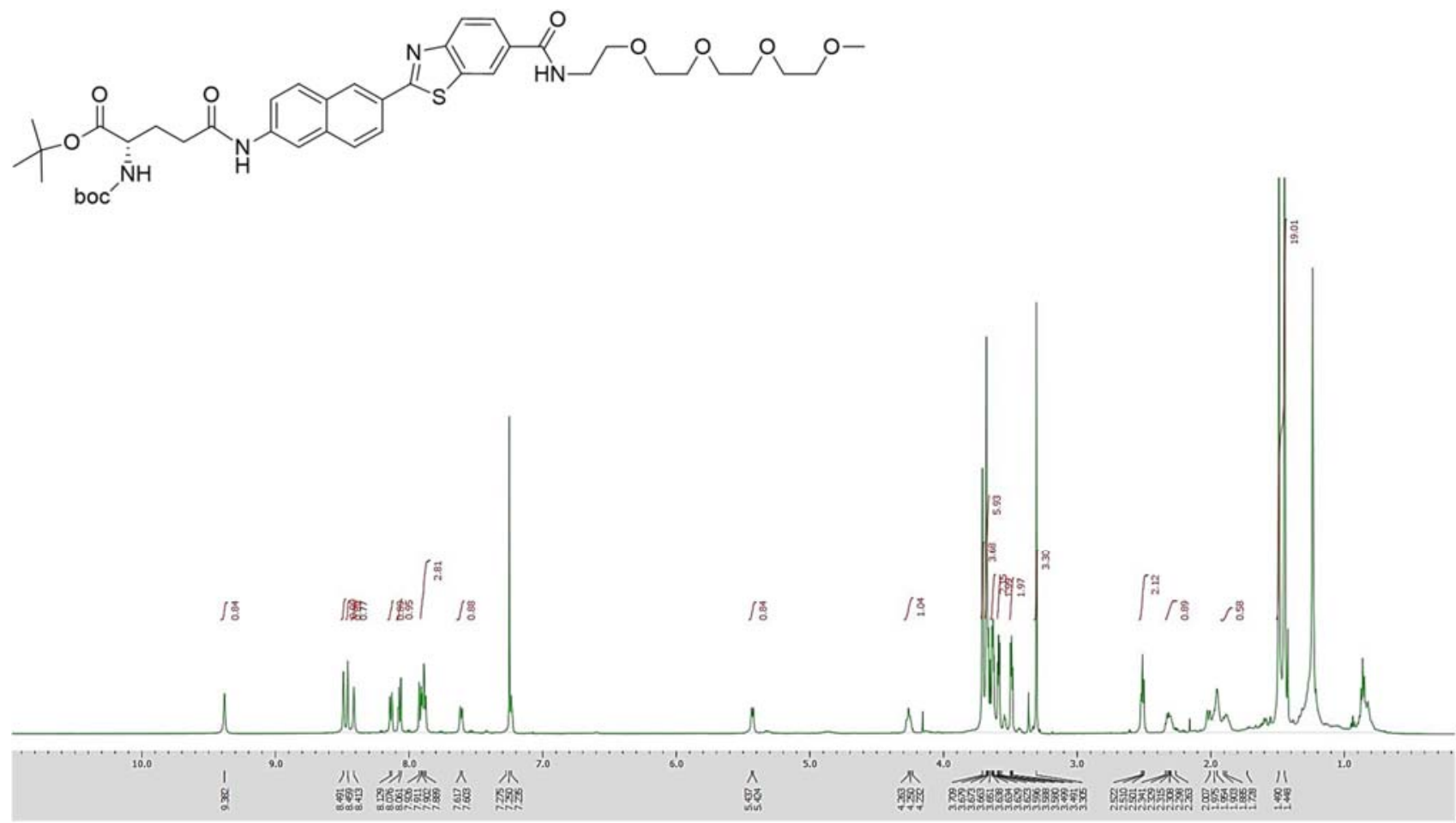

Figure S14. ${ }^{1} \mathrm{H}-\mathrm{NMR}$ spectrum $(600 \mathrm{MHz})$ of $\mathbf{H}$ in $\mathrm{CDCl}_{3}$ 

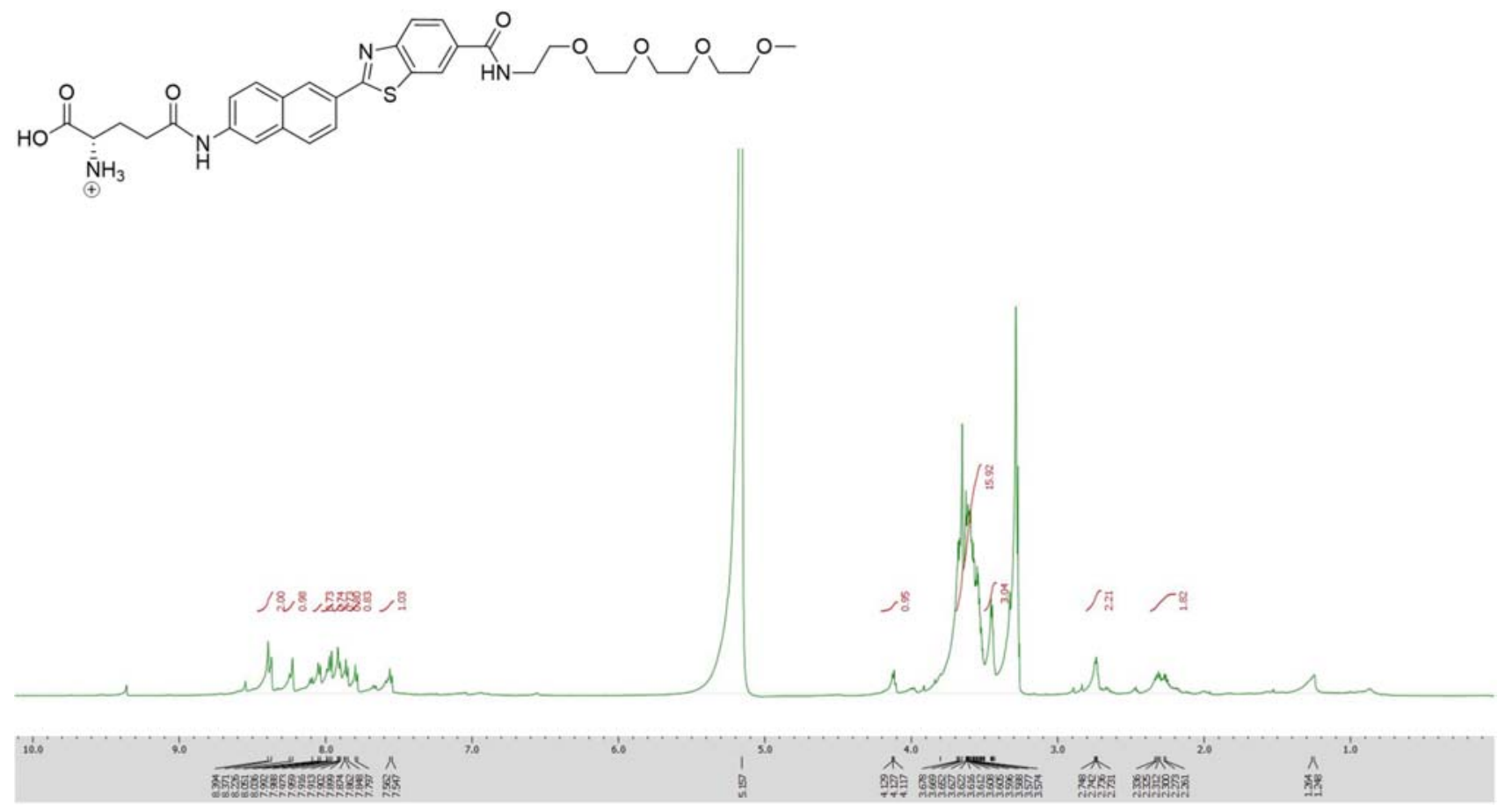

Figure S15. ${ }^{1} \mathrm{H}-\mathrm{NMR}$ spectrum $(600 \mathrm{MHz})$ of Probe2 in $\mathrm{CD}_{3} \mathrm{OD}$

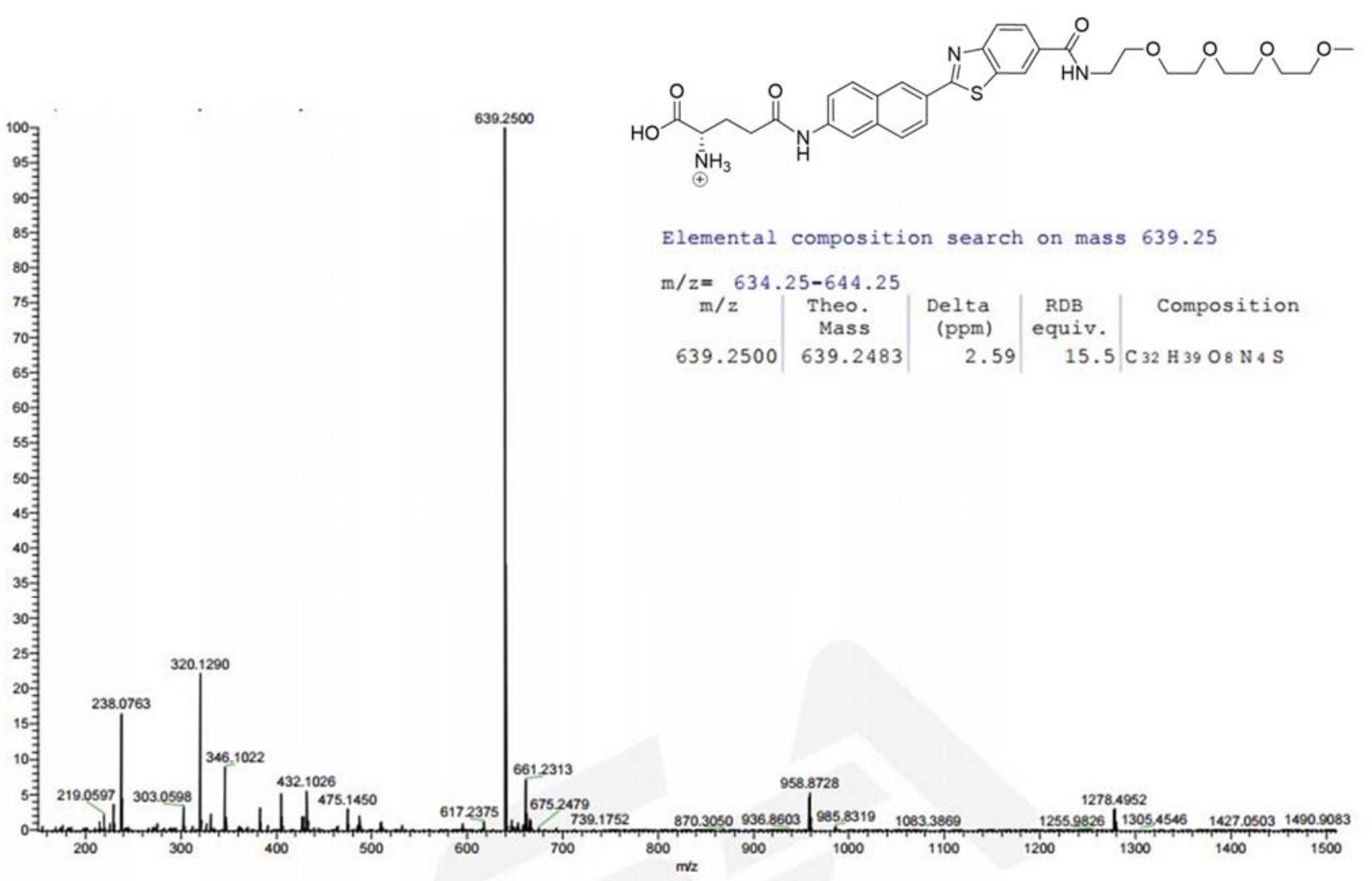

Figure S16. HRMS spectrum of Probe2 
<smiles>CN1c2ccccc2C(C)(C)C1/C=C/c1ccc2cc(N)ccc2c1</smiles>

Figure S17. ${ }^{1} \mathrm{H}-\mathrm{NMR}$ spectrum $(600 \mathrm{MHz})$ of 1 in $\mathrm{CD}_{3} \mathrm{OD}$ 2.100ug $2995-1043$ RT: $6.54-6.78$ AV: 12 NL: 924 E
F:FTMS + p ESI sid $=5.00$ Ful ms [150.00-1500.00]

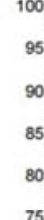

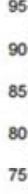$$
\text { 65- }
$$$$
\mathrm{m} / \mathrm{z}=322.19-332.19
$$

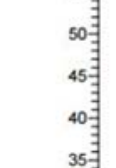

$$
35
$$

${ }^{35}{ }^{35}$

$$
\text { 20: }
$$

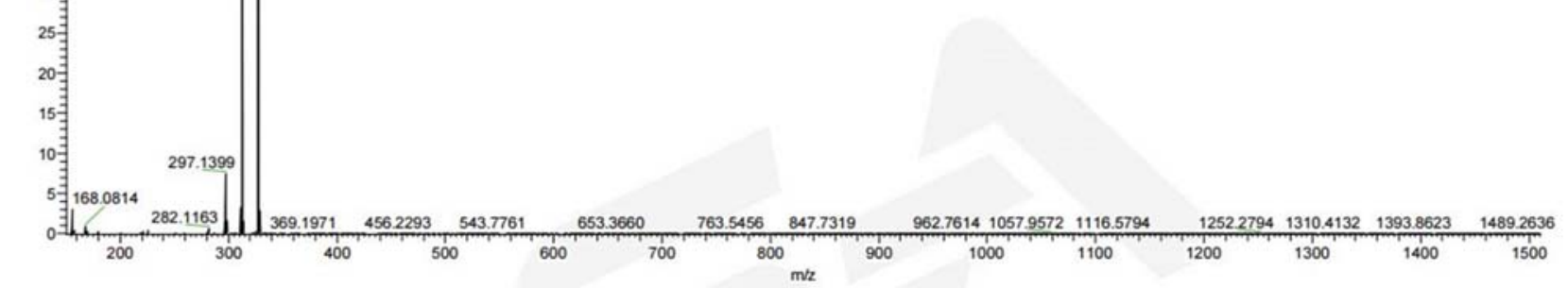

Figure S18. HRMS spectrum of 1 


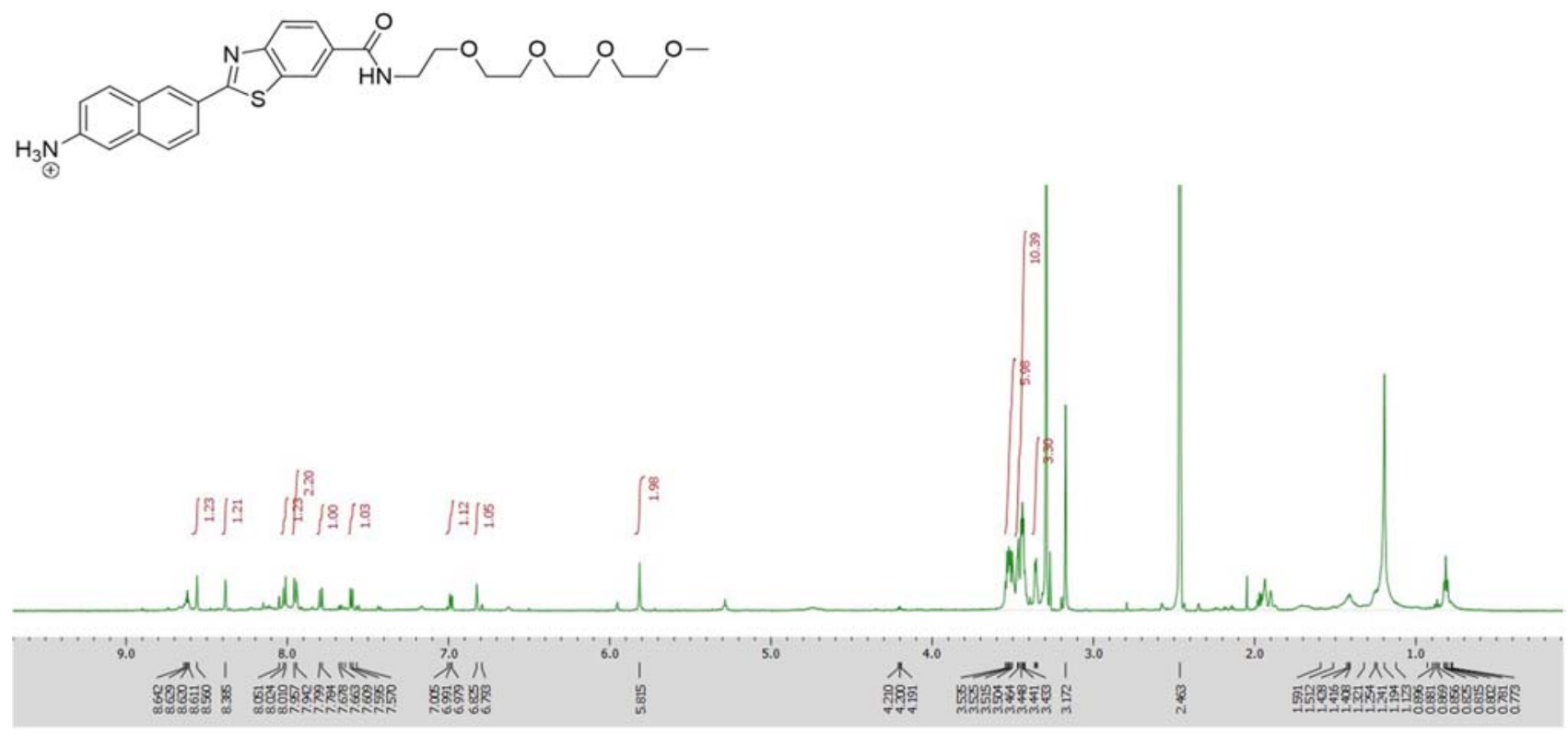

Figure S19. ${ }^{1} \mathrm{H}-\mathrm{NMR}$ spectrum $(600 \mathrm{MHz})$ of 2 in $\left(\mathrm{CD}_{3}\right)_{2} \mathrm{SO}$

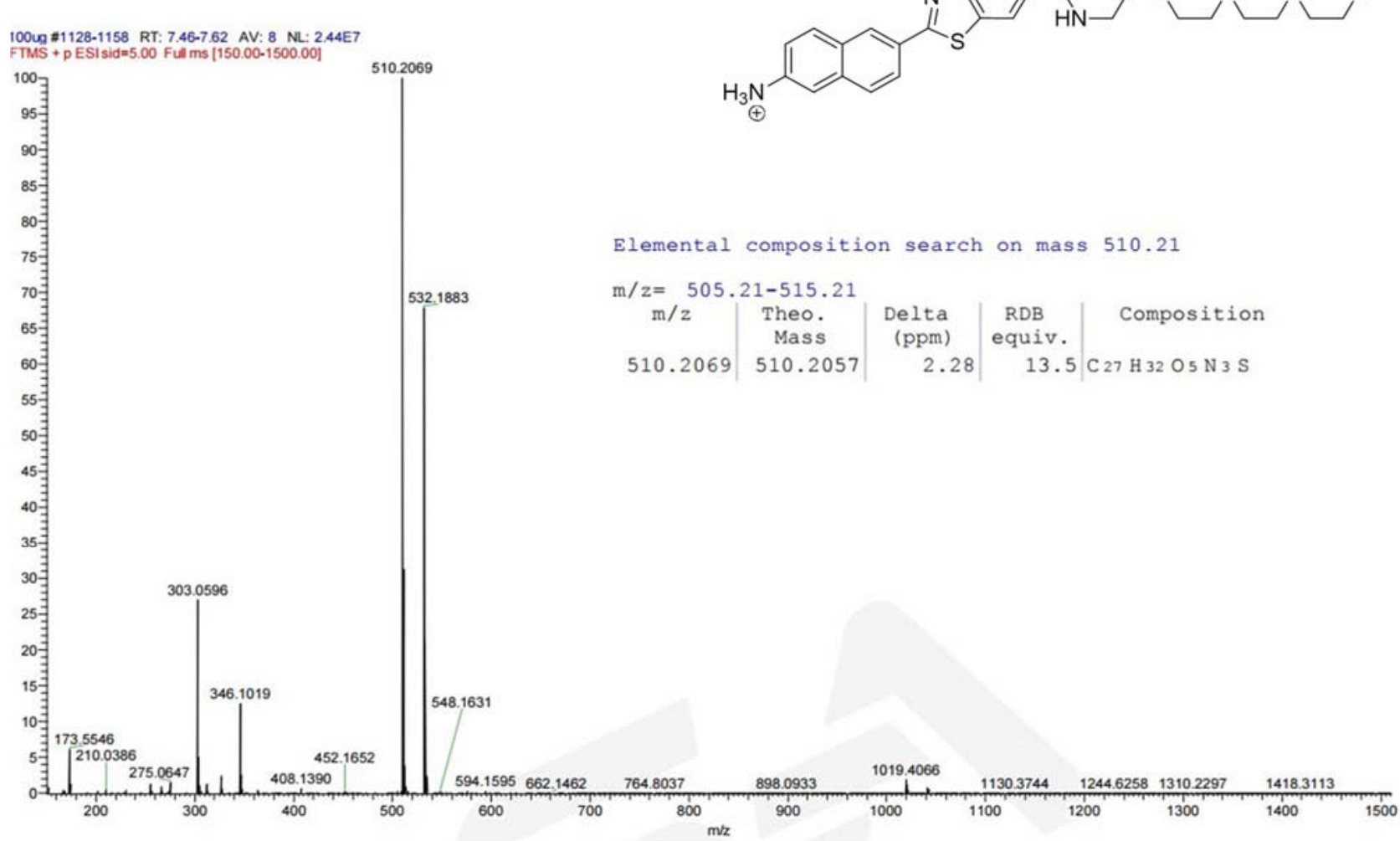

Figure S20. HRMS spectrum of $\mathbf{2}$ 


\section{References}

1. Lee, H. W.; Heo, C. H.; Sen, D.; Byun, H. O.; Kwak, I. H.; Yoon, G.; Kim, H. M. Ratiometric two-photon fluorescent probe for quantitative detection of beta-galactosidase activity in senescent cells. Anal. Chem. 2014, 86, 10001-10005.

2. Demas, J. N.; Crosby, G. A. Measurement of photoluminescence quantum yields. Review. J. Phys. Chem. 1971, 75, 991-1024.

3. Brouwer, A. M. Standards for photoluminescence quantum yield measurements in solution. Pure Appl. Chem. 2011, 83, 2213-2228.

4. Kim, H. M.; Choo, H. J.; Jung, S. Y.; Ko, Y. G.; Park, W. H.; Jeon, S. J.; Kim, C. H.; Joo, T.; Cho, B. R. A two-photon fluorescent probe for lipid raft imaging: C-laurdan. Chembiochem 2007, 8, 553-559.

5. Lee, S. K.; Yang, W. J.; Choi, J. J.; Kim, C. H.; Jeon, S. J.; Cho, B. R. 2,6-Bis[4-(pdihexylaminostyryl)styryl]anthracene derivatives with large two-photon cross sections. Org. Lett. 2005, 7, 323-326.

6. Makarov, N. S.; Drobizhev, M.; Rebane, A. Two-photon absorption standards in the 550-1600 nm excitation wavelength range. Opt. Express 2008, 16, 4029-4047. 